\title{
Fundamental Code of Natural Laws in Ifá Divination as Agents of Morality for Good Governance in Nigeria
}

\author{
Samuel Káyòdé Ọláléyẹ, PhD \\ African Traditional Religion \\ Department of Religious Studies \\ University of Ibadan, Ibadan \\ Oyo State, Nigeria \\ E-mail: kayodeleye2005@yahoo.com \\ Doi: https://doi.org/10.46222/pharosjot.102.041
}

\begin{abstract}
Ifá is the natural wisdom and knowledge concerning all life activities divinely revealed to Òrúnmilà by Olódùmarè, God in Yorùbá belief. It is the living foundation and custodian of the deity, moral, economic, language, religion, healing arts, tradition, culture and metaphysical orders. However, the concern of this paper is on the moral contents of the natural laws in Ifá corpus. Basically, there are two fundamental codes of natural laws in Ifá divination under which all other laws in Ifá exist. The first law enjoined every human being to acknowledge Olódùmarè as the Supreme Being and father of the universe who created all things. While the second law says "do unto others what you want them do unto you." However, it is quite unfortunate that, today, these laws that linked human relationships with the Supreme Being and the dos and don'ts of the divinities and those that hold the society together in harmonious relationships are no longer in proper use. This is evident in the lack of fear for the Creator, mismanagement of public funds, embezzlement and political killings, to mention a few. The purpose of this paper, therefore, is to examine the natural laws in Ifá and suggest how it can help sustain our fragile democracy as it did in the traditional society in the past for the sake of our future. The paper is premised on Matthew Flanagan's theory of divine commands which asserts that what is moral is determined by what God commands, and to be moral is to follow his commands.
\end{abstract}

Keywords: Natural laws, Ifá divination, morality, Ọrúnmìlà, divine commands.

\section{Introduction}

What is Ifá divination? This is the question that readily comes to the minds of anybody that hears the word. Ifá divination is the word of Olódùmarè that had been in existence since the establishment of the world ${ }^{1}$. It is natural wisdom and knowledge concerning all life activities given to by Olódùmarè. Although Ifá is not a philosophy, but it has a lot of concepts with philosophical issues. In it is the living foundation and custodian of the deity, economic, religion healing arts, metaphysical order as well as moral and a host of other virtues. Ifá is infinite source of knowledge - ìmò àmòn ì mòn tán ${ }^{2}$ that talks virtually about everything one can think of, including science of nature, animals, plants, incantations, divination, human and their nature with their peaceful

${ }^{1}$ Ifálere Odegbemi Odegbola, 2014, Iwe Mimo Ifá: Esin Akoda Olódùmarè, Ibadan: Odegbola Transitional Global Services, vii.

${ }^{2}$ M. Akin Makinde, 1988, African philosophy, culture and traditional medicine, Athens; University Center for international studies, 5 . 
coexistence with the aid of moral laws given by Olódùmarè and some more generated from this natural laws by the people.

Among the Yorùbá, Ifá is the potent source of having an insight into the future ${ }^{3}$. More importantly, it is the source of morality and ethical values of the society. Though Ifá is the word of Olódùmarè, He however, commissioned Orúnmilà to be in charge of this word for the benefit of humanity and other divinities. According to Adewale ${ }^{4}$, when he was sent to the earth by Olódùmarè on a mission to restore order and teach human beings the science of nature and the art of proper living (i.e. moral virtues), he was given the word of Olódùmarè that is known and called Ifá. Orúnmilà came to the world with the entourage of heavenly beings known and called Irúnmolè. They were the first inhabitants of the earth and Orúnmilà was their mouth piece. They spent a long time on earth and later ascended to heaven ${ }^{5}$.

After Orúnmilà had ascended to heaven, his disciples, known and called Babaláwo-lfá priests in Yorùbáland continued in the tradition he laid down till today. ${ }^{6}$ However, it is quite unfortunate that western civilization has led to the neglect of Ifá; the word of Olódùmarè thereby created a vacuum against its development, particularly the moral and ethical aspect of Ifá as we have in other religions like Christianity and Islam that are failing us today as a nation. Though they preach moral, they have little regards for ethical virtues. Do we then say that all religious truth lives within one tradition, and therefore, that anything outside such a tradition is wrong? Or can we assume that there is no truth in other sacred traditions but only in one, particularly one's own or in the case of Nigeria, in Christianity and Islam?

Our nation is in disarray because we have neglected our past and God given rules. What we have in place are insecurity, voodoo economy, political killings religious intolerance and many other social vices. To get out of the woods, therefore, this paper examined the natural laws in Ifá and offered suggestions on how it can help us sustains our fragile democracy as it was in the days of the natives for the sake of our future. The theoretical framework for this paper is premised on Mathew Flanagan theory of divine command that says what is moral is determined by what God commands. Therefore, to be moral is to follow the command of the creator. One may then ask, what is morality is all about, and what is the role of Ifá divination as agent of morality?

\section{What Morality is all about and the Roles Ifá Divination as a Moral Agent}

Morality is the principle concerning the distinction between what is right and what is wrong. It is about good and bad behaviour. It is a conformity with self-code, doctrine or system of rules or wishes of God, or how to behave with the norms of social behaviour. Looking at this with the laws or wishes of God, we still realise that morality depends on God. According to Dostoevsky ${ }^{7}$, if there is no God, then we won't be talking about right or wrong. As a result, everyone would go about doing whatever he/she like. Therefore, morality in his view, depends on God.

Looking at this from the Yorùbá traditional religion's perspective, we shall realize that Olódùmarè, in his words Ifá, through Òrúnmilà prescribed some natural laws to guide our behaviour and conducts toward Olódùmarè, divinities and fellow human beings. Òrúnmilà enjoined everyone to live at peace with God and fellow human beings in accordance with these laws. There, he teaches

\footnotetext{
${ }^{3}$ M. Akin Makinde 1988, African philosophy, culture and traditional medicine, Athens; University center for international studies,

${ }^{4}$ Aina Adewale Somadhi, 2008, Fundamental of the Yoruba Religion; Orisa Worship, San Bernadino, USA: Ile Orúnmila Communications, xxiii.

${ }^{5}$ Ifagbemi Yokelepekun, (Babalawo Ifa priest), Personal Interview, Apete, Ibadan, 10 ${ }^{\text {th }}$, July 2020

${ }^{6}$ C.L. Adeoye, 1979, Asa Ati Ise Yoruba, Ibadan: Oxford University Press, 9

${ }^{7}$ www.businessdictionary.com. Retrieved on 25/09/2015.
} 
that we should all love one another. According to Òrúnmilà, it is through this love for fellow human beings that happiness comes when one devotes one's time to the selfless service of other members of the community or country. This implies that if one truly loves his or her fellow being, there won't be killing, cheating, seduction, embezzlement, misappropriation of public funds, stealing and some other social vices.

Out of different means of articulating the divine mystery and different paths leading to it, Ifá divination is one and whole indivisible source of this mystery. According to Lucas, Ifá is the oracular deity, the most popular and most important in Yorùbáland ${ }^{8}$. Ifá is turned to for guidance and for ascertaining the will of Olódùmarè as regards the matter of the past, present and the future. All important events in life is referred to Ifá for its guidance and advice. Ifá is consulted in marriage relationships, friendships, kingship, chieftaincy, economic, political and religious matters. As said earlier, this Ifá is neither human worship rather, as written by Salami ${ }^{9}$ in his word, the divine message of Olódùmarè to the entire world.

Although Ifá is in possession of knowledge of several branches as said earlier, but knowledge of this surpasses the moral and ethical teachings of Ifá. This evidence in most of Ifá is available in both major and minor Odù's. Hardly do we see any chapter or verse of Odù that does not talk about one moral instruction or the other, directly or indirectly. Most of these moral teachings are either taught in proverbs, wise saying, or stories.

Some of these moral teachings of Ifá are found in natural laws given to humanity to guide our conducts among human beings, and our relationship with the divine begins and finally with Olódùmarè the Supreme Being ${ }^{10}$. The first of such natural laws is the one that enjoined human beings to acknowledge Olódùmarè as the Supreme Being and father of the universe who created all things. This is evidence in many Ifá chapters and verses. Both divinities and mankind were advised to worship Olódùmarè. According to Odù Òfún-sẹ́ ${ }^{11}$ Ifá says divinities acknowledged the supremacy and headship of Olódùmarè. There Ifá says;

Orí gbó kéké, idàndá gẹ̀ẹrè

Eruku yọmù Awo wọn lóde òrun

A dlfá fún gbogbo ọ̀kànlérúnwó Irúnmọlè

Wọ́n nlọ rèé gba isin nílé Olódùmarè l'óde ọrun

Eruku - yọmì a dé ò

Olódùmarè mo dé ò

Mo wá yìn ó ò o.
Ori gbo keke, Idanda geere

Eruku yomu the initiate in heaven

Ifa divination was performed for all the four hundred and one divinties

They were going to obtain worship at Olodumare's house in heaven

Erukuyomu we've arrived

Olodumare I'm around

I came to pay homage.

In the same vain, Òrúnmilà, the custodian of Ifá, also advised all mankind's to direct all its worship to Olódùmarè. Though one may wonder why he gives such an advice it is because a lot of people, particularly people from different faiths, hope and belief that the Yorùbá and Africans in general worship idols. This assertion had been argued several times that Africans do not worship idols. Rather, these divinities or the so called idols are just servants, errand boys and girls of the creator, Olódùmarè. It is undeniable in those days that people directed their worship toward the divinities, the concept that was not peculiar to the Africans alone, rather the whole world. However, the fact

\footnotetext{
8 J. Olumide Lucas, 1948. The religion of the Yorùbás, Lagos; CMS Bookshop. 71.

${ }^{9}$ Ayo Salami, 2008, Yorùbá Theology and Tradition the Genealogy, Lagos: NIDD Publishing Company, 11.

${ }^{10}$ William Bascom, 1969, Ifa Divination; Communication Between Gods and man in West Africa, London: Indiana

University Press, 104

${ }^{11}$ Adebowale Akintola, 1999, Yoruba Ethics and Meta Physics, Ogbomoso: Valour Publishing Venture Limited, 41
} 
remains that mankind knows that both the divinities and the spirits were created by Olódùmarè ${ }^{12}$. They also know that they (divinities and spirits) possess some qualities and powers that mankind do not have. Thus people tend to fear and reverence them. However with the advice of Òrúnmilà through Ifá, mankind re-established its commitment to worship Olódùmarè through these divinities. Àràbà Oláyẹmí, an informant sited Òșètúrá ${ }^{13}$ that attested to the above fact:

Òyè̀lè yelè

Ifá ní ká máa júbà Olórun

Torípé, oyin á șí

Oyin á lo ní kókó igi

Òyẹ̀lè nyẹlè

Ifá ní ká má a júbà Olórun

Ó ní lớjọ́ kan l'àfòmó yó lọ lórùn ò̀pe

Ó ní lợjó kan lòjijijièrè̀ yó relé Olódùmarè láfẹfé́

Ó ni lọjọ́ kan ni òun Ộnumilà yó șí nílé ayé.

Tí òun ó ròde òrun

Ó ní won a ní baba olóore lo

Baba tí í gbami lójó ibi

Ó ní njé nígbàyí

Ẹ é ma júbà mi pèlú Olódùmarè bí?
Oyele yele

Ifa says we should be paying homage to Go

Because bee will depart

Bee will go away from the tree

Oyele yele

Ifa says we should be paying homage to God

He says the parasite will depart from the palm tree

He says one day Ojijifere will go to the house of

Olodumare in a wind form.

He says he, Orunmila would one day migrate from this world,

That he would go to heaven

They would say a benefactor has gone

the father that rescue on evil days

He says then

Would you be paying homage to me?

In Odù Òsé-ìretè̀, Ifá also advised that it is important for mankind to serve, worship and venerate Olódùmarè, the self - existent being. In the Odù, Ifá says,

Ewé layé,

Gbòngbò ènìyàn nbe lóde òrun

$A$ difà fún Òrúnmilà,

Nijọ́ tí yíó mú ibà Olódùmarè wálé ayé

Ó fi nkó gbogbo wa,

Ó ní kí á má șe fi súrú pe eșú

Kí a má fi sùrù pe èșù òdàrà

Ó ní kí a má fi ewé irókò p'ewé oriro

Ká má fewé àgbágbà p'ewé àgbọn

Awá ta sílè kótó ta sẹnu,

Edùmàrè mà làgbà

Àwon tí wốn fi súrú pe sùrù

Ėdùmàrè mà làgbà

Àwọn tó nfewé irókò pewé àgbọn

Edùmàrè mà làgbà
The world is a leaf

Man's root is in heaven

Ifa divination was performed for Orunmila

On the day he will bring Olodumare's homage to the world

He taught every one of us

He says we should not misconstrue Suru for Esu

We should not misconstrue suru with Esu Odara

He says we should not misconstrue iroko's leaf for oriro's leaf

We should not refer to plantain leaf as coconut leaf

It will splash on the grand before mouth

Edumare ${ }^{14 * *}$ is supreme

Those that referred to suru as suru

Edumare is Supreme

Those that referred to irorko's leaf as coconut's leaf

Edumare is Supreme.

As a divine decree for humanity, Òrúnmilà teaches mankind never to mistake truth for falsehood. This is Olódùmarè's law to all living beings that established the sacredness of truth. It is sad to say that truth has eluded Nigeria as a nation. Rather than truth, we celebrate falsehood, greed,

\footnotetext{
12 E. Bolaji Idowu, 1962, Olodumare God in Yoruba Belief, Nigeria: Longman Nigeria Limited, 62.

${ }^{13}$ Araba Olayemi, Babalawo - Ifa Priest, Personal Interview, Ilaporu, $12^{\text {th }}$ September, 2020

$14 * *$ Edumare is the shorten form of the Supreme Being's name called Olodumare in Yoruba belief system.
} 
unrighteousness and other social vices. Besides, the above Odù explained that there is no substitute for Olódùmarè the Supreme Being that must be worshipped and feared. But the question is, if we truly fear and respect this God and his laws, Nigeria ought not to be experiencing what she is experiencing today. İwòri wòdin ${ }^{15}$ is also in support of the above assertion. According to the Odù, Ifá explained that:

\author{
A njowú Olórun ni \\ İbòsí Olódùmarè lawo nké \\ Bí a ní wọn ó kínni lẹhìn \\ Wọn a f'ègún sówó \\ Eni a ní ó fẹni lójú \\ F'ata sénu \\ Òpó à bá f'èyìn tì \\ Ikán ti múdí è je tán \\ Eni a ní á finú hàn \\ Jálárò kiri ẹni. \\ $A$ dífá fún gbogbo omo ènìyàn. \\ Won dorí kodò \\ Wọn npe Olódùmarè ní baba.
}

\author{
We are only envy God \\ We are only proclaiming Olodumare's might \\ If we ask for their support \\ They turn deaf ears \\ The one we rely on for assistance \\ Happened to be a wicked one \\ The pillar we ought to lean on, \\ Has been devoured by termites at the base \\ The person we intend to confide in \\ Is a talkative \\ Cast divination for the all human beings \\ They became pensive \\ They are referring to Olodumare as the father.
}

The second law established that we should do unto others what you want them do unto you. This is what Adebowale ${ }^{16}$ called the golden rule in his work. According to him, since no one likes to be killed, no one should kill another man. No one wants his property stolen; this indicates that no one should steal other person's property. No one admires a liar, therefore, we should endeavours to tell the truth and stand by it. These and so many others are the fundamental code of national laws that constitute the foundation of all ethics and moral laws all over the world. Somadhi ${ }^{17}$ was elaborate in her own exploitation of these laws. She identified sixteen of these laws in Odù Iká Ofún, which included ability to tell the truth, not to mislead people, not to deceive people, not to claim wisdom that they lacked, to be humble and never be egocentric, not to be treacherous, not to break taboos, respect the weak, the poor, the feeble and be nice to them, respect to the elderly, respect to moral laws, not to betray truths, not to disrespect and so on.

The laws of nature that says we should do unto others what we want them to do unto us enjoined us among other things to render selfless service to others. This is the reason why the Yorùbá would say or always say that "Öfi ti è sílè gbó tẹmi eléni, Òrișà òkè- Olódùmarè ni í ba a gbó tièwhoever devotes his time to help others, it is God that helps such a person. This is evidence in one of the informants assertion in Irósùn méj ${ }^{18}$ on this interpersonal relationship that;
Àkùkọ f'ogbe lếbẹ lẹ́bẹ șe’yi
The cock decorates itself with its comb
A dífá fún Òpílíkí
Tí ó fi tiè sílè
Tí ó ngbọ́ tẹni ẹlẹni kiri
Wọ́n ní èbo ni ki Òpílíkí rú
Òpílíkí gbébo nbè ó sì ru
İgà tó rúbo náà tán,
Wọ́n ní kí ó má a lo tún ti ọmo elòmíràn șe Ju ti ara rè lo
Ifa divination was performed for Opiliki
That abandons his work
That concentrates on other people's task
They told him to offer sacrifice
Opiliki yielded and perfomed the sacrifice
After he had performed the sacrifice,
He was told to concentrate the more on others
Than his own

\footnotetext{
${ }^{15}$ Fagboungbe Ibiyemi, Babawo- Ifa Priest, Personal Interview, Mokola, Ibadan, 24 ${ }^{\text {th }}$ September, 2020

${ }^{16}$ Adewale Akintola, 1999, Yoruba Ethics and Metaphysics, Ogbomoso: Valour Publishing Venture Limited, 98

17 Aina Adewale Somadhi,2008, Fundamentals of the Yoruba Religion; Orisa Worship, San Bernadino, USA: Ile

Orúnmila Communications, 12-13

${ }^{18}$ Fatoba Adedeji, an Ifa Priest, Personal interview, 26 ${ }^{\text {th }}$ August, 2021.
} 
İgbà tí tiè̀ ó dáa tán, ljó ni l jó, Ayọ̀ ni l yọ̀.

Ó ní kíni ó bámi túnwà a tèmi șe?

Érìgì àlò, Ifá ni ó bámì túnwà a tèmi șe. Erigi alo, Ifa will assist in reshaping my character.
After fortune had smiled on him, He started to dance He started to rejoice He says what will assist in reshaping his character?

What Ifá is saying here is that, the custodian of Ifá (we should note that Ifá is used for Òrúnmilà interchangeably by people because of their closeness) will intercede on behalf of the person that the divination was performed for before the creator -Olódùmarè. This is the primary responsibility of the divinities for mankind, and this is the reason why human beings offer them foods of all kinds and some other materials in form of ebo- sacrifice, for them to present our petitions very well before the creator. Another informant also speak about the truth as an ethical concept which is the most important of all the virtues. According to him, Ifá advised us in Odù Ejìogbè ${ }^{19}$ that;

\author{
Sòtító, \\ Sòdodo \\ Ení sòtító \\ Nimalè ngbè \\ Torípé, sèké sèké, șèké títí \\ Ó kú sójú iná, \\ Sọdàlè șòdàlè, sọdàlè títí \\ Ó kú sódàn oòrùn \\ Onínún ire sere títí \\ Ó kú, forí l'ajere ide \\ Ó kó owó méjèji lé orí omo ténté \\ A dífá fún Òrúnmilà \\ Ifá nșawo re'fè așèké \\ Ó nșawo re'fè așòdàlè \\ Ó nșawo re'fẹ̀ așòdodo...
}

\author{
Say the truth \\ Be honest \\ Whoever say the truth \\ Will be aided by the gods \\ Because the deceitful was so engrossed in deceit \\ That he died in the public \\ The treacherous was so engrossed in treachery that \\ He died in the open place \\ The benevolent was so engrossed in benevolence \\ That he died and rest in peace \\ He placed his two hands on his children \\ Ifa divination was performed for Orunmila \\ Ifa was on expedition to deceitful Ife town \\ Ifa was on expedition to treacherous Ife town \\ Ifa was on expedition to truthful Ife town
}

These and many other Odù are what Ifá advised us to include into our society to edify human for everyone to leave at peace. One may wonder what all these have got to do with governance in Nigeria. However, before we answer this question, it is important to make a critical work at the Nigerian governance.

\section{The Relevance of Natural Laws in Ifá as a Model for Good Governance}

In the traditional religion of the Yorùbá, and Africans in general, though Olódùmarè is physically absent on earth, everyone must love him as the Supreme Being, acknowledge him as the father of the universe and creator of all things. Ifá, the word of Olódùmarè is the author and custodian of all things that Olódùmarè created. Ôrúnmilà in turn was given the authority to care for this world of Olódùmarè because of his wisdom. As earlier said, Ifá is recognized all over Yorùbá land, Africa and the world in general. The truth in Ifá cannot be over emphasized and its laws are strictly obeyed by our forefathers. Good lessons derived from Ifá in those days are still in place and ardent devotees still obey and make use of them till today. Though there are great changes in the ways of doing things now. Nevertheless, obeying the laws, then made all things easy and convenient for our forefathers. For instance, in those days, in Yorùbá land, our forefathers will only use stone to indicate how much they wanted to sell their goods where there was no one to stay by such goods, especially beside the road to their respective farms. Any passersby who were interested in buying the goods would count the stone and drop the amount in monetary value

\footnotetext{
${ }^{19}$ Fatile Gbenga, Babalawo- Ifa Priest, Personal Interview, $27^{\text {th }}$ Inalende, September, 2021
} 
without taking more than the required goods or paying incomplete, inadequate money that was not in commensurate with the goods taken.

This is because they were aware and knew in their hearts that where there is no man, Olódùmarè is there. Therefore, their belief in Olódùmarè was so deep that they were always afraid to do evil. ${ }^{20}$ Besides, they also opined that whatever things they do on earth here, they are going to render account before the creator at the end of their life in the land of the living. This is the reason why Ifá priests always sing the song below;

Kámá șikà láyé21, Torí à ún rò̀run, Kámá șikà láyé o o ò

Torí à ún rọ̀run ùn, T’abá ti dé bodè, Aó rojọ́ 0.
We should not be wicked on earth

Because we are going to heaven

We should never be wicked on earth

Because we are going to heaven

When we get to heaven's gate

We shall surely give account of our deeds

Again, the second law that says do unto others what you want them do unto you that Somadhi ${ }^{22}$ explained in elaborate manner in Odù İká Òfún as part of several Ifá laws that guide Babaláwo and Ôrúnmilà followers is pertinent to everyone who practices Yorùbá religion through Ifá. This is where these laws are relevant. It could be a model for good governance in the sense that all that they preach, all that they advocate for in their religion, love, truth, peace, accountability, prudence in spending and a host of other social vices are what our political systems lack. By emulating these Babaláwo and the followers of Òrúnmilà, we hope that things will change for the better in Nigeria. Although we are not saying here that there are no few bad ones among the Babaláwo who sometimes deviates from these laws, yet the point remains that such bad eggs, where found among them, would be seriously warned, punished and eventually be sent packing if they refused to heed warnings. All the Babaláwo interviewed admitted that there are a few bad eggs among them but they are not afraid because if they are not found, they take solace in after life judgment of Olódùmarè who is going to judge according to every deeds. Besides, kò séni tó ma șikà t'ólórun kò ní dá léjọ́-no wicked man will escape the judgment of the creator. Ifá explained this in Odù İín-Ërín ${ }^{23}$ that:

İín arìnrìn morìn

İ́ín arìnrìn morìn

Ò bá rìn rìn rìn,

Kó o múgi àyin bòwálé

Enikan kò ní o ó yìn bó dọla

$A$ dífá fún orí,

Ó sawo títí ó fi gbadé

Orùn șawo títí ó gbèjighàrà ilèkẹ̀

Bèbè idi sawo títí,

Ó gba mósàáji așo oba tó koná yanranyanran.

A dífá fún Òrúnmilà

Ó șawo títí ó gba èbúbù ișu wálé...
Idin arinrin morin

Idin arinrin morin

You could have walk so long

And bring Ayin tree home

No one will praise you tomorrow

Ifa divination was performed for Ori

Who divined to the level of receiving a crown

The neck divined and collect expensive beads

The buttocks divined

Received expensive clothes

Ifa divination was performed for Orunmila

Who divined and receive half cut of yam

\footnotetext{
${ }^{20}$ E.A Lijadu, 1998, Ifa Mimo Alabalase Palero Kinni, Ondo: Ifeoluwa Printing Press, 1

${ }^{21}$ Ogunyemi Ojo, Babalawo- Ifa Priest, Oral Interview, Inalende Ibadan, 16 ${ }^{\text {th }}$ September 2021.

${ }^{22}$ Aina Adewale Somadhi, 2008, Fundamental of the Yoruba Religion; Orisa Worship, San Bernadino, USA: Ile

Orúnmila Communications, 17

${ }^{23}$ Ifalere Odegbemi Odegbola, 2014, Iwe Ifa Mimo: Esin Akoda Olodumare, Ibadan: Odegbola Traditional Global

Services, 196
} 
The four of them went to divine for Olófin, where they all prescribed for Olofin. Ori- head lied by prescribing crown and lots of money as sacrifice; the neck prescribed expensive beads and lots of money as sacrifice, while the buttocks prescribed expensive clothing and lots of money. It was only Òrúnmilà that did not lie in his own prescription of half cut of a tubal of yam and little money. They all went away with their prescriptions. Shortly after that, Orí- head, orun - neck and bebe $i d i$ - buttocks were sick. They had to offer those things they cunningly collected as sacrifice before they were okay. This is what gives good Babaláwo confidence that "Eni bá kánjú gba kókóró olà, ilè̀kùn àbámọ ni yí fi și kếyìn"- he who was in a hurry to get the key to riches will use the key to open the door of sorrow at the end. At least all the Babaláwo interviewed agreed with this assertion.

\section{Conclusion}

Ifá is the pathfinder of the Yorùbá. As confirmed by Òrúnmilà himself when he was leaving the world, that whatever one desires in life, one should ask Ifá for guidance. It is Ifá that will foretell about epidemic outbreak, diseases and so on. It is also Ifá that tells the type of sacrifice to offer to avert calamity. For peaceful co-existence, Ifá plays a big role. In fact, in a thousand and one things that the Yorùbá might try to do, Ifá is not left behind. In governance, installation of new king, chieftaincy taking and smooth running of government in those days in Yorùbá land, Ifá took preeminent position. Therefore there is nothing wrong in tapping some wisdom from Ifá, the source of our ancient beginning. This does not necessarily mean we are backward or uncivilized. Islam, Christian, Judaism and Buddhism among others are traditional religions of some people. They are not superior to Òrúnmilà's testament that Ifá represents. Just as we are receive wisdom and knowledge from these foreign religions, so also we can derive wisdom as it used to be in the past to direct our affairs in our own ways rather than adopting corrupt system.

To maintain a political stability in the country, political office holders should be ready to obey Olódùmarè's laws that will help them to be truthful in their dealing with public funds and the citizen, rather than paying lip service. Through the fear of God, they would stop killing people in the name of politics. When they realize that they cannot create, then they will not kill. With all these at the back of their minds, there would be free and fair elections when they realize that the law of Olódùmarè is all about love and truth, then they would be accountable to the electorates, thereby minimizing to the barest minimal, if it cannot eradicate mismanagement of public funds, all these put together will bring out the good leadership in them.

Besides, it is high time we took our culture seriously and made use of valuable things in it to better our social life. It is high time we re-discovered our nationalism and our wealth so as to liberate ourselves from the slavery, shackles and thralldom of western civilization and government that is not yielding the desired results. It is their own God given system and it is working for them. Therefore, our on will also work for us if we desire it. This would be a better world if the power of love replaces the love of power. Ifá divination would be of great help in this direction.

** Edumare is the shorten form of the Supreme Being's name called Olodumare in Yoruba belief system.

\section{References}

Adebowale Akintola. (1999). Yoruba Ethics and Meta Physics, Ogbomoso: Valour Publishing Venture Limited.

Adeoye, C.L. (1979). Asa Ati Ise Yoruba, Ibadan: Oxford University Press. 
Aina Adewale Somadhi. (2008). Fundamental of the Yoruba Religion: Orisa Worship, San Bernadino, USA: Ile Orúnmila Communications.

Akin Makinde, M. (1988). African philosophy, culture and traditional medicine, Athens; University Center for international studies.

Araba Olayemi. (2020). Babalawo. - Ifa Priest. Personal Interview, Ilaporu, $12^{\text {th }}$ September, 2020

Ayo Salami. (2008). Yorùbá Theology and Tradition the Genealogy, Lagos: NIDD Publishing Company.

Bascom, W. (1969). Ifa Divination; Communication between Gods and man in West Africa, London: Indiana University Press.

Bolaji Idowu, E. (1962). Olodumare God in Yoruba Belief, Nigeria: Longman Nigeria Limited.

Business Dictionary [Available online at www.businessdictionary.com]. Retrieved on 25/09/2015.

Fagboungbe Ibiyemi. (2020). Babawo - Ifa Priest. Personal Interview, Mokola, Ibadan, 24 ${ }^{\text {th }}$ September, 2020

Fatoba Adedeji. (2021). An Ifa Priest. Personal interview, 26 ${ }^{\text {th }}$ August, 2021.

Fatile Gbenga. (2021). Babalawo- Ifa Priest. Personal Interview, 27 ${ }^{\text {th }}$ Inalende, September, 2021

Ifálere Odegbemi Odegbola. (2014). Iwe Mimo Ifá: Esin Akoda Olódùmarè, Ibadan: Odegbola Transitional Global Services.

Ifagbemi Yokelepekun. (2020). (Babalawo Ifa priest). Personal Interview, Apete, Ibadan, 10 ${ }^{\text {th }}$, July 2020

Lijadu. E.A. (1998). Ifa Mimo Alabalase Palero Kinni, Ondo: Ifeoluwa Printing Press.

Ogunyemi Ojo (2021). Babalawo- Ifa Priest. Oral Interview, Inalende Ibadan, $16^{\text {th }}$ September 2021.

Olumide Lucas, J. (1948). The religion of the Yorùbás, Lagos; CMS Bookshop. 